\title{
Effect of Insulin Treatment on Prostacyclin in Experimental Diabetes
}

\author{
H. E. Harrison, A. H. Reece, and M. Johnson \\ Department of Biology, Imperial Chemical Industries, Macclesfield, Cheshire, England
}

\begin{abstract}
Summary. Diabetic patients have a high susceptibility to microvascular complications, atherosclerosis and thrombosis. Platelet hyperreactivity possibly related to an imbalance in arachidonic acid metabolism may be involved. Aortic rings or renal cortex produced a potent inhibitor of platelet aggregation, identified as prostacyclin $\left(\mathrm{PGI}_{2}\right)$. Release of $\mathrm{PGI}_{2}$ by tissues from streptozotocin - diabetic rats (aorta: $0.07 \pm 0.1 \mathrm{ng}$ / $\mathrm{mg}$ wet weight; renal cortex $0.004 \pm 0.001 \mathrm{ng} / \mathrm{mg}$ wet weight) was significantly depressed when compared with controls (aorta: $0.26 \pm 0.07 \mathrm{ng} / \mathrm{mg}$ wet weight; renal cortex: $0.009 \pm 0.001 \mathrm{ng} / \mathrm{mg}$ wet weight). Treatment of diabetic animals with insulin for 8 days restored $\mathrm{PGI}_{2}$ production to normal. The finding that $\mathrm{PGI}_{2}$ is depressed in the aorta and in the kidney, tissues which develop angiopathy, and that this is normalised by insulin, suggests that impaired $\mathrm{PGI}_{2}$ production, perhaps associated with platelet hyperreactivity may play a role in the vascular complications of diabetes.
\end{abstract}

Key words: Streptozotocin diabetic rats, prostacyclin, aorta, renal cortex, insulin treatment.

Patients with diabetes mellitus develop microvascular complications and have an increased susceptibility to atherosclerosis [1] and arterial thrombosis [2]. Disorders of blood coagulation and platelet function are reported to be particularly marked in diabetics with vascular disease [3]. This hypercoagulable state may be related to an imbalance in platelet [4] and vessel wall prostaglandin metabolism. We have previously demonstrated that the release of prostacyclin $\left(\mathrm{PGI}_{2}\right)$, a potent inhibitor of platelet aggregation, is significantly depressed in experimental diabetes [5] whilst the platelet production of thromboxane is significantly elevated [6]. In this study two approaches have been used to investigate the possible relevance of abnormal $\mathrm{PGI}_{2}$ to diabetic vascular disease. First, $\mathrm{PGI}_{2}$ levels in the kidney, a tissue susceptible to microangiopathy, have been estimated and secondly, the effect of insulin treatment on prostacyclin release by aorta and kidney from diabetic rats has been examined.

\begin{abstract}
Methods
Animals

Male rats (Alderley Park strain, 90-120 g body weight) were made diabetic by IV injection of streptozotocin $(80 \mathrm{mg} / \mathrm{kg}) 1-3$ months prior to use. Glucosuria was confirmed ('Clinistix') and blood samples $(0.5 \mathrm{ml})$ were taken from the dorsal aorta under ether anaesthesia at sacrifice, for glucose estimation by 'Technicon autoanalyser' [7]. Sex and age-matched rats were used as controls. In experiments to examine the effects of chronic insulin treatment, groups of diabetic rats were given single daily injections of a combination of semilente and ultralente (Wellcome) insulin for a period of eight days.

The animals had been diabetic for 27-30 days when insulin treatment was started. They received $60 \mathrm{U}$ semilente insulin per $\mathrm{kg}$ bodyweight and $60 \mathrm{U}$ ultralente insulin per $\mathrm{kg}$ on the first day, and $20 \mathrm{U}$ semilente $/ \mathrm{kg}$ and $80 \mathrm{U}$ ultralente $/ \mathrm{kg}$ on subsequent days. Physiological $(0.154 \mathrm{~mol} / \mathrm{l})$ saline was administered to groups of diabetic and non-diabetic controls. All injections were given subcutaneously in the morning ( $10 \mathrm{a} . \mathrm{m}$.). Blood samples $(25-50 \mu \mathrm{l})$ were taken for glucose estimation from the retro-orbital sinus before treatment and $23 \mathrm{~h}$ after each injection, and from the dorsal aorta at sacrifice. In one experiment, blood glucose levels were also estimated $4 \mathrm{~h}$ after injection. One animal from each group was sacrificed (by cervical dislocation) at hourly intervals throughout the day.
\end{abstract}

\section{Prostacyclin Estimation}

The abdominal aorta and right kidney were rapidly excised (approximately 2 mins) and immersed in Krebs Henseleit buffer (g/litre: - $\mathrm{NaCl} 6.92, \mathrm{KCl} 0.35, \mathrm{MgSO}_{4} 7 \mathrm{H}_{2} \mathrm{O} 0.29, \mathrm{CaCl}_{2} 0.28$, $\mathrm{KH}_{2} \mathrm{PO}_{4} 0.16, \mathrm{NaHCO}_{3} 2.1$, Glucose $2.0 ; \mathrm{pH} 7.4$ ) at $4{ }^{\circ} \mathrm{C}$ containing $200 \mathrm{mg} / 100 \mathrm{ml}$ glucose. The adventitial layer was removed from the aorta, and the vessel weighed and cut into fine rings $(1-2 \mathrm{mg}$ ). The rings were then suspended in the buffer at $60 \mathrm{mg} /$ $200 \mu$ l. Following removal of the capsule, the kidney was bissected longitudinally, and the cortex was excised, weighed, and homogen- 


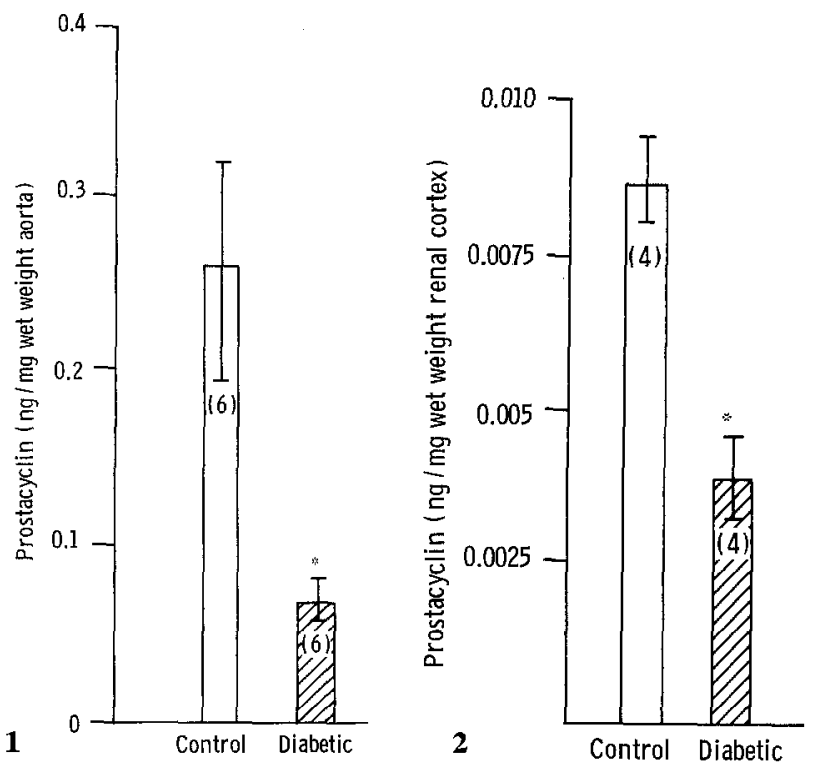

Fig. 1. Prostacyclin (ng/mg wet weight) released by the aorta of diabetic (blood glucose $412 \pm 15 \mathrm{mg} / 100 \mathrm{ml}$ ) and control (blood glucose $77 \pm 5 \mathrm{mg} / 100 \mathrm{ml}$ ) rats. Animals had been diabetic for 52 days at the time of the experiment. Numbers of animals in each group are shown in parentheses. Values represent mean \pm SEM. $* \mathrm{p}<0.02$

Fig. 2. Prostacyclin (ng/mg wet weight) production by homogenates of renal cortex of diabetic (blood glucose $343 \pm 31 \mathrm{mg} /$ $100 \mathrm{ml}$ ) and control (blood glucose $92 \pm 7 \mathrm{mg} / 100 \mathrm{ml}$ ) animals. Animals had been diabetic for 49 days at the time of the experiment. Numbers of rats in each group are shown in parentheses. Values represent mean \pm SEM.* $\mathrm{p}<0.01$

ised $(60 \mathrm{mg} / 200 \mu \mathrm{l})$ in Krebs Henseleit buffer on ice. Incubations were carried out at $22^{\circ} \mathrm{C}$ for $3 \mathrm{~min}$. Aliquots of the supernatant $(10-25 \mu \mathrm{l})$ were added to rat platelet rich plasma (containing $0.38 \% \mathrm{w} / \mathrm{v}$ trisodium citrate and $\sim 10^{9}$ platelets $/ \mathrm{ml}$ ), $30 \mathrm{~s}$ before the addition of a submaximal concentration of adenosine-5'diphosphate (ADP, 2 umol/l).

The activity of the supernatant in inhibiting platelet aggregation was measured in a double channel aggregometer ('Payton'). The quantity of $\mathrm{PGI}_{2}$ was estimated from a standard curve obtained in each experiment using chemically defined $\mathrm{PGI}_{2}$ (sodium salt), and expressed as ng/mg wet weight of tissue. Results are given as mean \pm SEM. Levels of significance were assessed using the Student $t$ test.

An antiserum was raised in rabbits to 5,6-dihydro $\mathrm{PGI}_{2}$ as the hapten conjugated to bovine serum albumin [8]. The antiserum $(1 \mu \mathrm{l})$ was incubated with platelet rich plasma for $30 \mathrm{~s}$ before the addition of either chemically defined $\mathrm{PGI}_{2}$ or supernatant. ADP was then added after a further $30 \mathrm{~s}$ and aggregation recorded. The platelet inhibiting activity of both $\mathrm{PGI}_{2}$ and of the supernatant was abolished by antiserum, whereas that of $\mathrm{PGE}_{1}$ and $\mathrm{PGD}_{2}$ was only slightly affected $(<15 \%)$.

\section{Results}

The incubated aortic rings and renal cortex released a potent inhibitor of platelet aggregation. This inhibitory activity was shown to be due to $\mathrm{PGI}_{2}$ by (a) loss of effect after boiling for $15 \mathrm{~s}$ [9] (b) relaxation of bovine coronary artery [10] and (c) inhibition by a specific antiserum.
The abdominal aorta from normal rats produced greater amounts of $\mathrm{PGI}_{2}(0.26 \pm 0.07 \mathrm{ng} / \mathrm{mg}$ wet weight) than inferior vena cava $(0.055 \pm 0.003 \mathrm{ng} /$ mg wet weight) under the same conditions.

The production of $\mathrm{PGI}_{2}$ by the aorta of diabetic rats $(0.07 \pm 0.01 \mathrm{ng} / \mathrm{mg})$ was significantly depressed $(\mathrm{p}<0.02)$ when compared with that of controls $(0.26 \pm 0.07 \mathrm{ng} / \mathrm{mg}$ ) (Fig. 1).

Homogenates of rat renal cortex in vitro generated less $\mathrm{PGI}_{2}(0.009 \pm 0.001 \mathrm{ng} / \mathrm{mg}$ wet weight $)$ than rings of abdominal aorta. As with aortic tissue, renal cortex from diabetic animals also released significantly less $\mathrm{PGI}_{2}(\mathrm{p}<0.01)$ than normal (Fig. 2).

\section{Effect of Insulin Treatment}

a) Aorta: Blood glucose levels in diabetic rats fell during the first two days of insulin treatment and were maintained at low level from days 3 to 8 (Fig. 3). The mean blood glucose in these animals 24 hours after injection was $111 \pm 14 \mathrm{mg} / 100 \mathrm{ml}$. Blood glucose levels remained high in diabetics treated with saline $(298 \pm 4 \mathrm{mg} / 100 \mathrm{ml})$ and low in control rats $(85 \pm 2 \mathrm{mg} / 100 \mathrm{ml})$.

$\mathrm{PGI}_{2}$ release from the aorta was depressed $(\mathrm{p}<$ 0.001 ) in diabetic rats treated with saline (Fig. 4). Insulin treatment significantly increased $\mathrm{PGI}_{2}$ production $(p<0.05)$ and there was no difference between values for these animals and controls.

b) Renal Cortex: In this experiment, mean blood glucose levels 24 hours after injection were $163 \pm 15$ and $395 \pm 11 \mathrm{mg} / 100 \mathrm{ml}$ in diabetic animals treated with insulin and saline respectively, and $99 \pm 3 \mathrm{mg}$ / $100 \mathrm{ml}$ in controls. Renal cortex from diabetic animals treated with saline produced significantly reduced amounts of $\mathrm{PGI}_{2}(\mathrm{p}<0.01)$ (Fig. 5). Insulin treatment resulted in increased cortical $\mathrm{PGI}_{2}$ production. There was no significant difference between $\mathrm{PGI}_{2}$ production in insulin treated animals and nondiabetic controls.

\section{Discussion}

Platelet abnormalities including increased reactivity $[4,11]$, spontaneous aggregation [12], decreased survival [13], elevated prostaglandin (PG) [4] and malonyldialdehyde [14] production and $\beta$-thromboglobulin release [15], are found in diabetes and are particularly marked in patients with vascular complications.

The activation of platelets initiates the sequential conversion, by cyclo-oxygenase, of arachidonic acid to the intermediary PG endoperoxides. Endoperoxides can be converted to $\mathrm{TxA}_{2}$ [16] or $\mathrm{PGE}_{2}, \mathrm{PGD}_{2}$ and $\mathrm{PGF}_{2 \alpha}[17]$ by platelet thromboxane synthetase and $\mathrm{PG}$ isomerases respectively, or to $\mathrm{PGI}_{2}$ by 


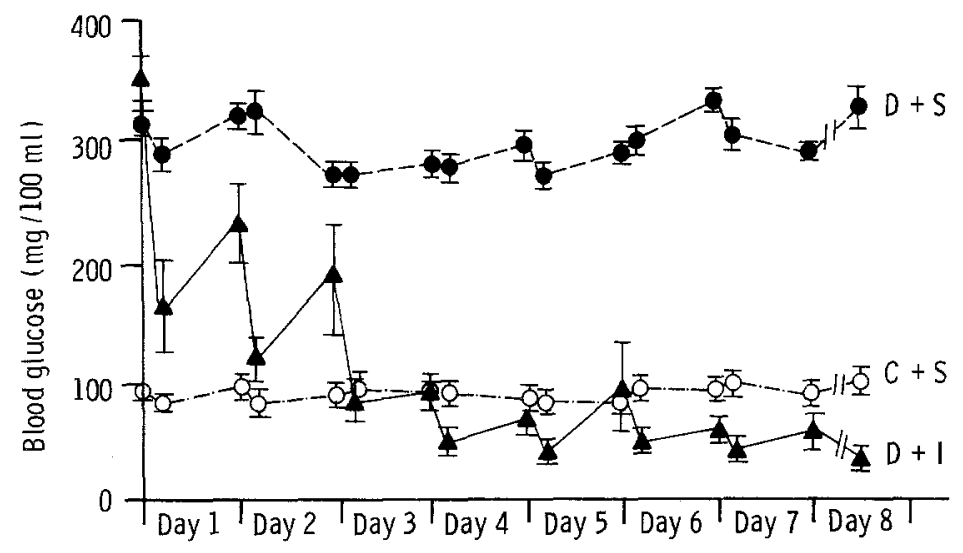

Fig. 3. Mean blood glucose levels ( \pm SEM) in $\mathrm{mg} /$ $100 \mathrm{ml}, 4$ and 24 hours after injection, in diabetic rats treated with saline $(D+S)$, or insulin $(D+I)$ and control rats treated with saline $(C+S)$. Final values represent blood glucose levels at sacrifice. There were six animals in each group

endothelial cell prostacyclin synthetase [18]. TxA $\mathrm{A}_{2}$ is a potent constrictor of vascular smooth muscle [19] and induces platelet aggregation [20], whereas $\mathrm{PGI}_{2}$ elicits vasodilation [21] and prevents platelet aggregation or induces disaggregation [22]. A biological balance is therefore maintained between activated platelets and the functional endothelial cell.

We have demonstrated that vascular $\mathrm{PGI}_{2}$ is decreased and that platelet $\mathrm{TxA}_{2}$ is elevated in experimental diabetes $[5,6]$ and in diabetic patients [23]. A deficiency in endothelial cell $\mathrm{PGI}_{2}$ production, resulting in an inability to cope with the platelet release of $\mathrm{TxA}_{2}$ and mitogenic factors [24] could be involved in the vascular complications of diabetes. This is supported by our finding that $\mathrm{PGI}_{2}$ is depressed in the kidney, a tissue which develops microangiopathy.

High rates of $\mathrm{PGI}_{2}$ production do not occur in the presence of high blood glucose [5]. Prostacyclin is restored to normal by chronic, but not by acute, insulin administration. The effectiveness of chronic insulin may be explained by the longer duration of treatment or by the greater decrease in blood glucose levels at sacrifice (chronic: $30 \pm 3 \mathrm{mg} / 100 \mathrm{ml}$, acute: $179 \pm 23 \mathrm{mg} / 100 \mathrm{ml}$ ). At present, we are unable to distinguish between these possibilities. However, if prolonged insulin treatment is necessary, then this suggests that a repair process is occurring and that the depressed $\mathrm{PGI}_{2}$ in diabetes may be due to endothelial cell loss or damage. Alternatively, if the level of blood glucose is critical then hyperglycaemia or an associated metabolic abnormality of diabetes may be responsible. It has been previously shown that increased glucose concentrations [25] and osmolality [26] decrease PG synthesis.

Studies in diabetic animals have shown that insulin treatment or pancreatic islet transplantation decreases the severity of renal [27] and retinal [28] lesions and diminishes ocular fluorescein leakage [29]. There is also evidence from clinical studies that good metabolic control slows the progression of retinopathy [30] and nephropathy [31]. Furthermore, the development of microangiopathy in normal kid-
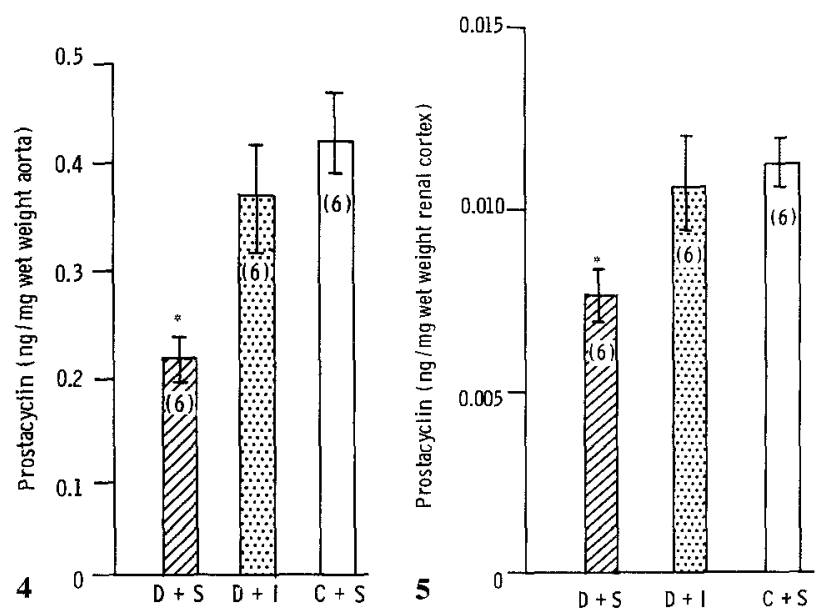

Fig. 4. Prostacyclin (ng/mg wet weight) released by the aorta of diabetic rats treated with saline $(D+S)$ or insulin $(D+I)$ and control rats treated with saline $(C+S)$. The numbers of animals per group are shown in parentheses. Values represent mean \pm SEM. $\mathrm{p}<0.001$ versus $\mathrm{C}+\mathrm{S}$ and $\mathrm{p}<0.05$ versus $\mathrm{D}+\mathrm{I}$ where indicated $(*)$

Fig. 5. Production of prostacyclin (ng/mg wet weight) by homogenates of renal cortex from saline-treated $(D+S)$ and insulintreated diabetic rats $(D+I)$ and saline-treated controls $(C+S)$. Values represent mean \pm SEM. $p<0.01$ versus $C+S$ where indicated $\left(^{*}\right)$

neys following transplantation into diabetic subjects [32] suggests that metabolic factors play a role in small vessel disease. Evidence for a favourable effect of good control on large vessel disease in the diabetic is lacking, although glucose intolerance is known to be a risk factor for cardiovascular disease [1].

If, as these studies suggest, improvement of the metabolic abnormalities of diabetes prevents, or slows, the progression of vascular disease, then the finding that insulin treatment restores prostacyclin to normal is compatible with the suggestion that impaired vessel wall prostaglandin metabolism could play a role in the evolution of diabetic angiopathy.

Acknowledgement. We are indebted to Dr. K. Gibson, Chemistry Department for synthetic prostacyclin, Dr. B.Furr, Biology 
Department for antiserum to prostacyclin and to Mrs. T. E. Robinson, Mr. M. J. A. Arnstein, Mrs. S. Jones and Miss S. Bowden for technical assistance.

\section{References}

1. Keen, H.: Glucose intolerance, diabetes mellitus and athersclerosis prospects for prevention. Postgrad. Med. J. 52, $445-457$ (1976)

2. Goodale, F., Daou, A. S., Florentin, R., Lee, K. T., Gittelsohn, A.: Chemico-anatomic studies of arteriosclerosis and thrombosis in diabetics. I. Coronary artery wall thickness, thrombosis and myocardial infarction in autopsied North Americans. Exp. Mol. Pathol. 1, 352-363 (1962)

3. Heath, H., Brigden, W. D., Canever, J. V., Pollock, J., Hunter, P. R., Kelsey, J., Bloom, A.: Platelet adhesion and aggregation in relation to diabetic retinopathy. Diabetologia $7,308-315$ (1971)

4. Halushka, P. V., Lurie, D., Colwell, J. A.: Increased synthesis of Prostaglandin - E - like material by platelets from patients with diabetes mellitus. N. Engl. J. Med. 297, 1306-1310 (1977)

5. Harrison, H. E., Reece, A. H., Johnson, M.: Decreased vascular prostacyclin in experimental diabetes. Life Sci. 23, 351-356 (1978)

6. Johnson, M., Reece, A. H., Harrison, H. E.: Decreased vascular prostacyclin in experimental diabetes. Adv. Pharmacol. Chemother. 4, 865 (1979)

7. Barham, D., Trinder, P.: An improved colour reagent for the determination of blood glucose by the oxidase system. Analyst 97, 142-145 (1972)

8. Bunting, S., Moncada, S., Reed, P., Salmon, J. A., Vane, J. R.: An antiserum to 5, 6-dihydro prostacyclin $\left(\mathrm{PGI}_{1}\right)$ which also binds prostacyclin. Prostaglandins 15, 565-573 (1978)

9. Moncada, S., Gryglewski, R., Bunting, S., Vane, J. R.: A lipid peroxide inhibits the enzyme in blood vessel microsomes that generates from prostaglandin endoperoxides the substance (prostaglandin X) which prevents platelet aggregation. Prostaglandins 12, 715-736 (1976)

10. Dusting, G. J., Moncada, S., Vane, J. R.: Prostacyclin (PGX) is the endogenous metabolite responsible for relaxation of coronary arteries by arachidonic acid. Prostaglandins 13, 3-15 (1977)

11. Kwaan, H. C., Colwell, J. A., Cruz, S., Suwanwela, N., Dobbie, J. G.: Increased platelet aggregation in diabetes mellitus. J. Lab. Clin. Med. 80, 236-246 (1972)

12. Breddin, K., Grun, H., Krzywarek, H. R., Schremmer, W. P.: On the measurement of spontaneous platelet aggregation: the platelet aggregation test. III. Methods and first clinical results. Thromb. Haemostas. 35, 669-691 (1976)

13. Ferguson, J. C., Mackay, N., Philip, J. A. D., Sumner, D. J.: Determination of platelet and fibrinogen half life with ${ }^{75}(\mathrm{Se})$ selenomethionine: studies in normal and diabetic subjects. Clin. Sci. Mol. Med. 49, 115-120 (1975)

14. McGuire, M. B., Ward, J.D., Russell, R. G. G., Best, L. C., Preston, F.E.: Increased malonyldialdehyde production in vitro by platelets from patients with diabetes mellitus. (Abstract), p. 531. XVII Congress of Haematology, Paris, July 1978

15. Preston, F. E., Ward, J. D., Marcola, B. H., Porter, N. R., Timperley, W. R., O'Malley, B. C.: Elevated $\beta$-thromboglobulin levels and circulating platelet aggregates in diabetic microangiopathy. Lancet 1978 I, 238-239

16. Needleman, P., Moncada, S., Bunting, S., Vane, J. R., Hamberg, M., Samuelson, B.: Identification of an enzyme in platelet microsomes which generates Thromboxane $\mathrm{A}_{2}$ from prostaglandin endoperoxides. Nature 261, 558-560 (1976)
17. Hamberg, M., Samuelson, B.: Detection and isolation of an endoperoxide intermediate in prostaglandin synthesis. Proc. Natl. Acad. Sci. USA 70, 899-903 (1973)

18. Herman, A. G., Moncada, S., Vane, J. R.: Formation of prostacyclin $\left(\mathrm{PGI}_{2}\right)$ by different layers of the arterial wall. Arch. Int. Pharmacodyn. Ther. 227, 162-163 (1977)

19. Needleman, P., Minkes, M., Raz, A.: Thromboxanes: Selective biosynthesis and distinct biological properties. Science 193, 163-165 (1976)

20. Hamberg, M., Svensson, J., Samuelson, B.: Thromboxanes - a new group of biologically active compounds derived from prostaglandin endoperoxides. Proc. Natl. Acad. Sci USA 72, 2994-2998 (1975)

21. Szczeklik, A., Gryglewski, R. J., Wizankowki, R., Musial, J., Pieton, R., Mruk, J.: Circulatory and antiplatelet effects of intravenous prostacyclin in healthy men. Pharmacol. Res. Commun. 10, 545-556 (1978)

22. Moncada, S., Gryglewski, R., Bunting, S., Vane, J. R.: An enzyme isolated from arteries transforms prostaglandin endoperoxides to an unstable substance that inhibits platelet aggregation. Nature 263, 663-665 (1976)

23. Johnson, M., Harrison, H. E., Raftery, A. T., Elder, J. B.: Vascular prostacyclin may be reduced in diabetes in man. Lancet 1979 I, 325-326

24. Ross, R., Glomset, J., Kariya, B., Harker, L.: A platelet dependent factor that stimulates the proliferation of arterial smooth muscle cells in vitro. Proc. Natl. Acad. Sci. USA 71, $1207-1210$ (1974)

25. Tennenbaum, J., Nies, A. S., Aulsebrook, K., Sweetman, B., Oates, J. A.: Release of prostaglandins from rat renal papilla in vitro: Effect of glucose concentration. Fed. Proc. 35, 223 (1976)

26. Praag, D. V., Farber, S. J.: Effect of increased osmolality on prostaglandin metabolism in rabbit kidney. Fed. Proc. 35, 223 (1976)

27. Fox, C. S., Darby, S. C., Ireland, J. T., Sönksen, P. H.: Blood glucose control and glomerular capillary basement membrane thickening in experimental diabetes. Br. Med. J. 1977 II, 605-607

28. Engerman, R., Bloodworth, J. M. B., Nelson, S.: Relationship of microvascular disease in diabetes to metabolic control. Diabetes 26, 760-769 (1977)

29. Scharp, D., Krupin, T., Waltman, S., Oestrich, C., Feldman, S., Ballinger, W., Becker, B.: Relationship of abnormal insulin release to fluorophotometry in experimental diabetes. Diabetes 27, 435 (1978)

30. Kohner, E. M., Fraser, T. R., Joplin, G. F., Oakley, N. W.: The effect of control on diabetic retinopathy. In: The treatment of diabetic retinopathy. Goldherg, M. F., Fine, S. L. (Eds.), p. 119-124. Washington: US Public Health Service No. 1890 1969

31. Takazakura, E., Nakamoto, Y., Hayakawa, H., Kawai, K., Muramoto, S., Yoshida, K., Shimizu, M., Shinoda, A., Takeuchi, J.: Onset and progression of diabetic glomerulopathy. Diabetes 24, 1-9 (1975)

32. Mauer, S. M., Barbara, J., Vernier, R. L., Kjellstrand, C. M., Buselmeier, T. J., Simmons, R. L., Najarian, J. S., Goetz, F. C.: Development of diabetic vascular lesions in normal kidneys transplanted into patients with diabetes mellitus. N. Engl. J. Med. 295, 916-920 (1976)

Received: January 30, 1979, and in revised form: August 6, 1979

Dr. M. Johnson

Department of Biology

Imperial Chemical Industries

Alderley Park

Macclesfield, Cheshire

England 